NBER WORKING PAPER SERIES

INTERNATIONAL POLICY COORDINATION IN HISTORICAL PERSPECTIVE:

A VIEW FROM THE INTERWAR YEARS

Barry Eichengreen

Working Paper No. 1440

NATIONAL BUREAU OF ECONOMIC RESEARCH

1050 Massachusetts Avenue

Cambridge, MA 02138

September 1984

Prepared for the National Bureau of Economic Research/Centre for Economic Policy Research Conference on International Policy Coordination held in London, June 28-29, 1984, and forthcoming in the conference volume. This paper was written during visits to Stanford University and INSEE. I am grateful to Paul David and Jacques Melitz for helpful discussions, and to the French Ministry of Foreign Affairs, the French Ministry of Finance and the Controller of H. M. Stationery office for permission to refer to the Public Records. The French Ministry of External Affairs provided financial support. The research reported here is part of the NBER's research program in International Studies and project in Productivity (World Economy). Any opinions expressed are those of the author and not those of the National Bureau of Economic Research. 


\section{Internationa 1 Policy Coordination in Historical Perspective: \\ A View from the Interwar Years}

\section{AB S TRACT}

This paper examines the international financial relations of the interwar period to see what light this experience sheds on current concerns over international policy coordination. The analysis proceeds in three parts. The first part considers the role for policy coordination as viewed by contemporaries at the start of the period; it takes as a case study the Genoa Economic and Financial Conference of 1922. Efforts at Genoa to coordinate policies ended in failure; the second part therefore considers the effects of noncooperative strategies within the framework of the interwar gold standard. The analytical model developed in this section suggests that the failure to coordinate policies lent a deflationary bias to the world economy which may have contributed to the onset of the Great Depression. The third part asks what policymakers learned from this failure to coordinate policies, taking evidence from the next effort to establish a framework for international financial collaboration: the Tripartite Monetary Agreement of 1936.

Barry Eichengreen

Department of Economics Harvard University Cambridge, Massachusetts 02138 (617) $495-1871$

National Bureau of Economic Research 1050 Massachusetts Avenue Cambridge, Massachusetts 02138 


\begin{abstract}
"Measures of currency reform will be facilitated if the practice of continuous cocperation among central banks of issue, or banks regulating credit policy in the several countries can be developed. Such cooperation of central banks, not necessarily confined to Europe, would provide opportunities of coordinating their policy, without hampering the freedom of the several banks."
\end{abstract}

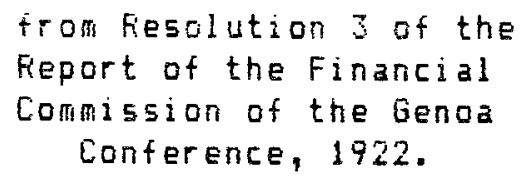

In the days of the gold standard, it is sometimes said, international policy coordination was a moot point. 1 Popular accounts based more on caricature than on careful historical analysis portray the gold standard as a remarkably efficient mechaniso for coordinating the actions of national authorities. Policies were so easily reconciled, it is argued, because those responsible for their formulation, regardless of nationality, shared a belief of balanced budgets and a common overriding objective: pegging the domestic currency price of gold. When central banks intervened in financial markets, it is suggested, they did so mechanically, obeying "rules of the game" which dictated that they only reinforce the impact on domestic money and credit markets of balance of payments conditions. For example, a central bank losing reserves would raise its discount rate while the central bank gaining reserves would lower its discount rate, thereby reinforcing one another's efforts to restore external balance. Hence monetary policy under the gold standard is a favorite example of those who argue that international policy coordination is most readily achieved under a rules-based regime rather than one that depends on discretion.

This naive vision of the days of the gold standard as a simpler, more 
harmonious era is at best partial and at worst misleading. The very actions of central banls suggest that their objectives were not in fact so easily reconciled by the operation of gold standard constraints. Discount rates tended to move together, not inversely as the "rules of the game" would suggest. ${ }^{2}$ Central banks sterilized international gold flows more often than they intervened to reinforce their impact on domestic markets. 3 These and other actions resemble the outcome of a noncooperative game, in which the participants act to neutralize rather than accommodate the efforts of their counterparts. Yet on occasion central banks and governments mariaged to achieve cooperative solutions to their problemis, such as when they negotiated swap arrangenents, earmarled gold, or extended international loans. 4 Goth central banks and governments clearly recognized their interdependence, if they did not always succed in coordinating their actions.

still, it is fair to say that the interwar period opened the modern era of interdependence. In the 1920 s questions of policy coordination and central bank cooperation acquired a new tone of urgency. In part this reflected greater opportunities for coordinating policies in a world with a Fank for International Settlements, an international telegraph, and a trans-Atlantic telephone. 5 In part it reflected the higher costs of ignoring interdependence in a world of rapid communication, integrated markets and volatile capital flows. Above all it reflected the widening scope for conflict as governments attached growing importance to domestic economic objectives and put less weight or balance of payments targets. The interwar period provides examples of various forms of successful collaboration. The League of Nations provided statilization loans to countries experiencing hyperinflation in return for their accession to protocols which precluded their central banks from monetizing budget 
deficits and committed then to return to gold. International conferences held at Erussels in 1920 and Genoa in 1922 laid the basis for reconstructing the international monetary system. The United States saw Eritain's return to gold as the linchpin upon which the gold standard's resurrection depended, and it provided credits of $\$ 300$ million to facilitate Britain's restoration of the prewar sterling parity. ${ }^{6}$ These efforts were fully successful in reconstructing the international system: once its renewal had teen signaled by Eritain s return to gold, some fifty nations joined the U.S. and the U.K. as participants in the interwar gold standard.

Yet the interwar period provides equally dramatic illustrations of failures of cooperation and their costs. The trief duration and early demise of the interwar gold standard is taken to indicate the inability of major participants to effectively coordinate their actions. A prime Example is the failure of the countries at the center to harmonize their choice of parities. The important cases are Great Eritain, where overvaluation of sterling was associated with unprecedented levels of unemployment and depression in the export trades; and France, where undervaluation of the franc was associated with sustained economic growth and until 1931 insulation from the worst effects of the Great Depression. One corollary of this competitive imbalance was an uneven international distribution of gold. Nations such as the United states and France whose international competitive positions were relatively strong acquired and retained a large portion of the world's monetary gold, leaving others such as Eritain to defend the convertibility of their currencies on the basis of slender reserves. Another indication of this inability to coordinate policies was the widespread failure to play by the rules of the 
gold standard game; instead central banks sterilized international reserve flons and tesitated to adjust their discount rates in response to external pressures.

This paper takes a new look at the financial history of the interwar period to see what light this experience sheds on current concerns over international policy coordination. After a review of the literature and the historical preconditions, it tells a story in three parts. The first part examines the role for policy coordination as envisaged by contemporaries at the start of the period. It takes as a case study the Genoa Economic and Financial Conference of 1922 . We will arque that the advantages of policy coordination were in fact well understood in the 'twenties but that political disagreements impeded efforts to establish a mechanismi for cooperative action. Instead, policymalers ultimately pursued noncogperative strategies within the frameworl of the international gold standard.

The second part coneiders the effects of noncooperative behavior once the gold standard was again in operation. Identifying these effects requires an explicit model. Yet the idea of strategic behavior by national authorities is wholly incompatible with standard models of the gold standard's operation. The analysis therefore requires the development of an alternative model of the interwar gold standard. While the model developed below bears little resemblance to previous frameworks used to analyze gold standard adjustment, it indicates clearly not only the Edvantages of coordinated action but suggests why cooperative solutions proved so difficult to achieve.

The final part concerns the question of what the principal partieipants learned from their pursuit of noncooperative strategies. The lessons of the interwar gold standard as they were understood by 
contemporaries found reflection in the next attempt to reconstruct the international monetary order: the Tripartite Monetary Agreement concluded by Eritain, France and the United States in the autumn of $1936 .^{7}$ The terms of the Tripartite Agreement were remarkably similar to the Genoa Resolutions of 1922. Where they differed was in the absence of favorable references to fined parities and to the gold-emchange standard. They differed as well by mare tightly circumscribing the range of issues subject to collatoration. This along with the decline of political obstacles to cooperation permitted the noble sentiments of the Tripartite Agreement to LE implemented. Thus, the nistory of international financial collatoration in the interwar period sheds light rot only on the rationale for policy coordination tut also on the circumstances conducive to its practice.

\section{Leadership and Cooperation Under A Gold Standard Regime}

In theoretical treatments of the gold standard's operation, there is no scope for policy coordination. The adjustment process works autonatically, affecting surplus and deficit countries alike. The pricespecie-flow variant of the adjustment mechanism emphasizes the role of relative prices in restoring external balance. A gold outflow leads to monetary deflation and falling prices until the international competitiveness of the goods produced by the deficit country is enhanced sufficiently to restore equilibrium to the external accounts. The monetary variant of the adjustment mechanism stresses the role of wealth and real balance effects. A gold outflow reduces absorption through the real balance effect on consumption until the equality of income and expenditure is restored. In Each case, the surplus country is affected symmetrically. Beyond standing ready to buy and sell gold at the official price, the only role for central banks is to mechanically reinforce the impact on domestic money and credit 
markets of incipient gold flows.

Strikingly, these theoretical treatments bear little resemblance to historical analyses of the gold standard's operation either at the end of the 19 th century or between the wars. Where theoretical models describe central banks as mechanically reinforcing one another's actions, historical accounts emphasize instead the potential for conflict between national authorities and their strategic interaction. Yet in none of these accounts is the scope for conflict adequately defined, leaving unclear the advantages of leadership and cooperation.

Historical descriptions of the classical gold standard place great weight on asymmetries in the system's operation. Great gritain in particular is seen as possessing unrivaled abilities to manipulate the process of edjustment. Eritain's market power is attributed to her position as the world's foremost trading and lending nation. Eritish exports, which had already quadrupled between 1800 and 1850 , increased Eightfold between 1850 and 1913, and on the eve of the first World War Eritain accounted for 14 percent of world exports, a figure far exceeding her share of world production or income. The world's principal organized commodity marlets all were centered in England. Not the least of these was the London gold market, which reqularly received the bulk of South Africa's gold production. In addition, Britain had no close competitor as the world's preeninent international lender. By 1913, Eritish overseas investments amounted to nearly 45 percent of the external investments of the major creditor countries of the Hest. Britain's annual capital export was nearly five times that of France, her nearest rival. Never before or since have a nation's overseas investments been such a large share of national income. 
Britain's commercial and financial preeminence had profound

implications for the international role of eterling, which had implications in turn for the operation of the adjustment mechanism. Sterling was the world's leading vehicle currency in international transactions. Trade that neither touched Eritish shores nor passed through the hands of British merchants overseas might nonetheless be invoiced in sterling. Transactions the world over were settled with the transfer of sterling balances between foreign accounts maintained in London. Securities denominated in sterling were the most popular form of international reserves with which central banke might supplement their stocks of gold.

Under these circunstances, it is arqued, the Eant of England exercised powerful leverage over international flows of comodities, capital and gold - leverage it could employ to manipulate the process of adjustment by which external balance was restored. Changes in Eank Rate the rate charged by the Eank of England for loans to discount houses and other dealers in Treasury and commercial bills) exerted an influence not shared by foreign discount rates and to a large extent determined credit conditions not merely at home but abroad. 10 A rise in Eank Rate is typically thought to have forced up the required rate of return on Treasury and commercial bills, and by rendering these assets more attractive increased the opporturity cost to the banking sector of extending loans and overdrafts to borrowers. Given the share of sterling loans and advances in international markets for short-term capital, rates of return on foreigncurrency-denominated assets that were substitutes for sterling were forced up as well. Moreover, because the world's most important gold market also was located in London, the Eank of England by altering the cost and availability of short-term credit directly influenced the tendency of nonresidents to purchase and ship abroad gold newly delivered to market. 
To paraphrase Walter Eagehot's famous aphorism, rasing gank Rate to a sufficiently high level would succeed in dpawing gold from the moon. This leverage over capital flows followed from the fact that no foreign. power could match the gank of England's influence in international financial markets. The United States, without even a central bank, lacked the resources and the expertise to rival Eritain in the market. The gank of France's sphere of influence was limited to Russia and France's colonial possessions. Foreign authorities possessed no feasible alternative but to respond to Bank of England initiatives, as the British understood. Hence, the Eank of England could anticipate with considerable accuracy the response of foreign authorities to a change in Bank Rate in London, and it could frame its policy accordingly. To the Deputy Governor of the Bank of England keynes described the reaction of foreign governments in the following way: "In prewar days it used to be maintained--I think truly-that to a large extent we led the world; that is to say, if we reduced Bank rate it protably brought about a corresponding reduction in the rates in other countries." 11 As he framed the arqument when helping to draft the report of the Macmillan Comattee, Eritain could "by the operation of her Eank fiate almost immediately adjust her reserve position. Other countries had, therefore, in the main, to adjust their conditions to hers." 12

There is little agreement on the costs and benefits of the Bank of England's exercise of leadership. The benign view of the prewar arrangement is that it operated to the benefit of both the leader and her followers by permitting the participants in the gold standard syste to economize in their use of gold. The Bank of England could maintain a slender gold reserve because she had the power to reverse a gold outflow 
through unilateral initiative. Other central banks, such as those of France, Germany, Austria-Hungary and Fussia, had less leverage over financial flows and were therefore forced to hold larger reserves in order to accomodate wider swings in their reserve positions. But due to the Bank of England's capacity to operate with relatively slender reserves, the gold backing of the world's monetary base could be efficiently reduced. Since the Eank of Ergland's leverage over international capital flows erased any lingering doubte about the convertibility of sterling, other countries were encouraged to supplement their holdings of gold with this key currency, further auginenting international reserves to the benefit of all concerned.

A less Eanguine view is that through her eyercise of market power Eritain was capable of shifting the burden of adjustment abroad. Triffin has argued that, due to London's singular importance as a source of credit for financing international transactions in foodstuffs and raw materials, Eritain was through the impact of Bank Rate overseas more than compensated for the economic costs of stringent credit conditions. 13 The argument is that a tefforary credit stringency swung the terms of trade in Britain's favor by increasing the cost to foreign producers of carrying stocks of primary products. Given the higher cost of holding inventories, stocks of foodstufts and raw materials were dumped onto world markets, reducing the cost of British imports. Obviously, carrying costs were important as well to Eritish producers of manufactured exports, who had the same incentive as producers of primary commodities to liquidate stocks in the face of tighter credit conditions. Assuming however that the market for primary products was characterized by exceptionally low price elasticities of demand, Britain's international terms of trade would still have improved on balance. 14 
By the interwar periad, it i f frequently suggested, circumstances had been transformed. Eritain no longer poseessed unparalleled influence over the international adjustment mechanism. Other nations had acquired sufficient leverage to formulate if not independent then at least distinctive national policies, leaving the Bank of England in no better position than its rivals to ignore developments atroad. In particular, the interwar period has been characterized as the era when London declined at the expense of New York. 15 The war and its aftermath had transformed the United States from a net debtor to a net creditor, and she suddenly found herself in possessioi of a large share of the world's monetary gold. When Eritain returned to gold in 1925, U.S. gold reserves here roughly 5 ix times those of the Bank of England. The Eritish government owed the U.S. \$4.7 billion in war detts, although their ultimate magnitude and the schedule by to which they might be refaid renained very much in doubt. Moreover, Hashington was newly equipped with a Federal Reserve Eoard and New York with a Federal Feserve Eank to direct and carry out financial market intervention.

Through the first part of the 'twenties New York surpassed London as a source of funds invested abroad. The U.k.'s share of world export value declined from 14 percent in 1913 to barely 12 percent in 1925 and little more than 11 percent in 1928. Eefore the War, Britain had consistently run current account surpluses; in the century ending in 1913 there had been but two years of deficit. The situation was different between the wars; in the short span from 1925 to 1931 there were already two years of current account deficit. 16 Bankers and merchants, finding themselves to be dealing with both financial centers and running down the balances on sterling accounts maintained in London, increasingly held diversified 
portfolios of the two key currencies.

The Eritish position was not eased by concurrent developments in France. Unlike Britain, France's share of world trade was stable after 1913. Following de facto stabilization in 1926 at a rate which undervalued the franc, France's external position remained strong until Eritain's devaluation in 1931. In 1928, when de jure convertibility of the franc was restored, the gank of france's holdings of liquid sterling assets roughly matched in value the Gank of England's entire gold reserve. Qver the next four years, the fank of France engaged in a persistent effort to convert these talances into gold as part of a conscious policy of elevating Paris to the stature of a first-rank financial center. 17

The Eritish authorities recognized their heightened interdependence with foreign nations. In particular, the gank of Englard found it impossible to neglect the reaction of foreign central banks to a prospective change in Bank Fate. Were the Gank of England to disregard foreign reactions when setting its discount rate, it would "render itself liable to be flooded with, or depleted of, gold, as the case may be." As high an official as the Deputy Governor of the Eank of England admitted that "such leadership as we possessed has certainly been affected by the position which American has gained." 18

While policymakers clearly recognized their heightened interdependence, the implications of this recognition remain somewhat unclear. One literature attempts to document the stimulus this recognition of interdependence provided for cooperative action. For example, Clarke (1967) describes instances where central banks extended to one another routine clearing services, shared privileged information, and arranged international stabilization loans. Another literature emphasizes the inability of policymakers to coordinate their actions despite this 
recognition of interdependence. Thus, Viner (1932, p. 28) and Gayer (1937, p. 29) describe London, Paris and New York as having worked at "crosspurposes." Yet it is not easy to extract from their analyses a sense of. how working at cross-purposes affected the operation of the monetary system. In part this is due to the tendency of these authors to argue by analogy rather than specifying the economic model they have in mind. Nevin (1955, p. 12) is typical of this mode when, likening the international monetary system to an automotile, he characterizes Eritain and the United States as "two quite excellent orivers...perpetually fighting to gain control of the vehicle." A system influenced by the actions of two financial centers, like a car with two orivers, will function only if those centers are capable of cooperating and acting consistently. But, he goes on, "in the real world, this seldom happens, and the existence of more than one centre with powers of control leads to the existence of more than one policy." What we would like to know is whether the presence of two chauffeurs causes the car to be driven too fast, too slow, or too erratically, and what the implications of the chauffeurs behavior is for the welfare of the passengers.

Arguments by analogy, however appealing, provide no answer to these questions. The historian's instinct is to turn to the documents for guidance. The economist's is to construct a model. We consider these approaches in turn.

\section{The Genoa Conference of 1922 and the Role for Cooperation}

When the Genoa Economic and Financial Conference convened in April 1922, European exchange and trade relations were in disarray. Physical devastation in the main theaters of the war created persistent excess demands for foodstuffs and raw materials, particularly in Central and 
Eastern Europe. Capital goods imports were needed to replace plant and Equipment destroyed in the course of the war. Yet the nations of Continental Europe possessed limited resources out of which to finance the required imports. Industrial and agricultural production remained well below 1913 levels. 19 The United States curtailed and quickly eliminated official lending to its European allies, insisted on prompt repayment of its war loans, and constrained Europe's capacity to earn foreign exchange by sharply raising tariff rates. Europe therefore turned to deficit spending to finance economic reconstruction. 20 some such as the French proceeded on the premise that Reparations payments would Eventually permit any new debt to be retired and prewar monetary arrangements to be restored. Others such as the Germans were preoccupied almost entirely by the immediate problem of reconstruction. Ey the summer of 1920 the mark had already begun its descent; the franc, in contrast, fluctuated uneasily in response to new information about prospects for Reparations.

In Western Europe and the United States, the Armistice had been followed by a sudden and dramatic boom. Consumers finally were permitted to vent demands that had been pent up during the war, and producers took the opportunity to replenish their stocks. In Britain the pressure of demiand led to an inflation of prices unprecedented in peacetimes Employment expanded rapidly, and wages rose in response. In light of these inflationary pressures, the Bank of England raised its discount rate in November 1919 and April 1920. Almost simultaneously, industrial production turned down, and unemployment among trade union members rose from 1.4 to 16.7 percent within a year. Wholesale prices fell by nearly 50 percent between the spring of 1920 and the beginning of 1922. In France wholesale 
prices turned down in May, falling by 41 percent within a year, while the index of industrial production fell by eight percent between 1920 and 1921. In the United States fluctuations in industrial production, while not as pronounced as in Eritain, followed basically the same pattern, while wholesale prices fell by 45 percent in the 10 months following thejr May 1920 peak. 21

As in the 1970s, financial instability impeded efforts to liberalize international trade. Since the major belligerants had all inposed trade controls in the course of the war, they had in place the administrative machinery needed to administer import licensing and quota schemes. While some such as Britain rapidly moved to dismantle wartime controls, others such as France, which initially emulated the Eritish example, turned back to tariff protection once their currencies tegan to depreciate. Trade with central Europe was further depressed by the slow recovery of these economies. Together with the embargo on Russian trade, the prospects for an export-led recovery appeared dim.

The Reparations question cast a shadow over attempts at monetary reconstruction and impeded efforts to arrange cooperative solutions to Europe's financial problems. The provisions of the Treaty of Versailles designed to provide a mechanism by wich realistic Reparations claims might be negotiated were disabled by the refusal of the U.S. Congress to ratify the Treaty. The Treaty itself deferred final determination of the amount of Reparations but required an initial payment of 200,000 inilion gold marks, the first installment falling due in May 1921.22 when the Reparations Commission, staffed not by financial experts but by politicians taking instructions from their governments, finally determined the value of Reparations in April 1921, the amount was fixed at $\$ 32$ billion, three times the sum recommended by the economic experts at Versailles and a much larger 
amount than the Germans anticipated. In principle, the transfer might be made by payment in gold, payment in services, or payment in commodities. Yet the Reichsbank's gold reserve barely amounted to one semi-annual Reparations payment. German guest workers would scarcely be welcomed in neighboring countries already experiencing high unemployment. Thus, Germany had no alternative but to attempt to finance its transfer through an export surplus. The value of the transfer Germany might have accomplished given the impact of a surplus on her terms of trade has been detated ever since. 23 The only certainty from the point of view of financial market participants was that the magnitude and timing of Reparations payments would remain uncertain, with unkrown implications for the public finances of the major creditor countries.

This was the background against which the Genoa Conference of 1922 was convened. Genoa was only one in a series of international monetary and financial conferences held in the 19205 , and negotiations there were not unrelated to previous meetings at Brussels in 1920 and at Cannes in January 1922. For example, the participants in the Erussels conference had issued declarations which resembled in general terms the resolutions subsequently adopted at Genoa. However, only at Genoa were the particulars of these proposals specified and methods for implementing them through the international coordination of policies given explicit consideration.

The countries with greatest influence over the proceedings at Genoa were the United States, France and Eritain. The three nations approached the Conference with very different objectives. Despite other differences the Americans and the British shared a common interest in rebuilding the international economy. The leaders of both nations agreed that recovery required the revitalization of foreign trade, for which reconstruction of 
the gold standard Has a necessary prerequisite. Beyond these general goals, however, the tho sets of policymalers had little in common. The British were willing to go considerably further than the Americans to promote the expansion of trade. They hoped that diplomatic and comercial relations with the Soviet government could be estatished and that Reparations could be reduced. To facilitate the renegotiation of Reparations, they suggested that the United states forgive at least a portion of its war debt claims. With this groundwork laid, they hoped that the creditor countries would be encouraged to extend loans to the European dettors, promoting economic recovery on the continent and stimulating

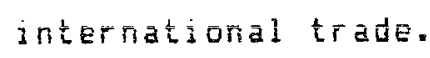

While restoring sterling's prewar parity was seen as an essential element of monetary reconstruction, the Eritish were wary of the economic costs that the deflation associated with restoration might entail. From their perspective the preferred solution was inflation abroad rattier than deflation at home - in particular, inflation in the United States. The Eritish contemplated various schemes to encourage the fimericans to inflate, ranging from subtle diplomatic pressure to a far-fetched plan to inmediately pay in gold a large share of Britain's war debt in order to drastically expand the American monetary base. 24 This last seheme was dismissed due to the likelihood of American sterilization and its impact on the Hank of England's reserve position. It would be preferable for monetary expansion to be initiated abroad and backed as necessary by reserves of foreign exchange. That a significant portion of foreign exchange reserves would be held in the form of sterling undoubtedly figured in British calculations. 25

Although the Americans shared Britain's interest in promoting the expansion of world trade, from their vantage point the problem was less 
pressing. They were willing to participate in discussions of international economic policy only as part of a general settlement. While Herbert Hoover and his Secretary of State, Charles E. Hughes, expressed an interest in convening in what the President termed a "real honest-to-god econonic conference" designed to reestablish fined exchange rates, international convertiblity and free international movements of commodities and gold, they evinced little enthusiasm for meetings like those at Genoa which seemed likely to concentrate on stop-gap measures to be adopted in lieu of balanced budgets or Reparations settlements, and whose success appeared to hinge on American concessions regarding war debts. 26 In the end, Hughes agreed only to send to the conference as an unofficial observer the Ainerican Ambassador to Rome, Richard Washburn Child.

In contrast to the Americans, the french sought to define the agenda for Gerioa as narrowly as possible. The French opposed Eritish proposals for universal adoption of nondiscrimination in trade and the most-favorednation clause, so they sought to discourage discussion of a general convention on trade policy. In contrast they pressed for discussion of sanctions against the Soviet Government on the question of prewar debts. 27 This dispute intensified after January 1922, when Briand's relatively moderate government was replaced by a more nationalistic administration headed by Poincare, who commenced almost immediately to spar over these issues and Reparations with the equally combative Lloyd George. Foincare was skeptical about the usefulness of multilateral negotiations and agreed to participate in the conference only on British assurances that France's position on Reparations, the terms of the Treaty of Versailles, and the Russian Imperial Government's debt to France would not be questioned. 28 
The monetary proposals discussed at Genoa originated with the Eritish delegation. In drafting their proposals the Eritish could draw on the First Interim Report of the Cunliffe Comittee and on the considerable talents of their monetary 5pecialists, notably Ralph G. Hawtrey, since 1919 Director of Financial Enquiries at H.M. Treasury. 29 A number of Britain's Genoa proposals resembled the Cunliffe Committee's recommendations, including the argument that a credible comintment to financial stability required a return to gold. 30 Resurrecting the gold standard, it was stated, required balancing government budgets, insulating central banks from pressure to eatend credit to government agencies, and consolidating national debts. Little was novel in these ideas. More novel were the measures first proposed by the cunliffe Committee and incorporated into the gritish proposals to economize on the demand for monetary gold: these included eliminating internal circulation of gold coin, concentrating gold reserves at the central bank, and permitting domestic residents to acquire coin and bullion for export only from the authorities. By limiting the use of gold to international settlements, the Cunliffe Committee and the Eritish delegates at Genoa sought to minimize compting demands for reserves.

The British draft was circulated among foreign authorities in Fetruary 1922, and in March experte from Eelgium, France, Italy and Japan met with Eritish representatives in London to undertake revisions. These proposals were adopted with only slight modification by the Financial Committee at the Genoa Conference in April and by the Conference itself in May. 31

The Genoa resolutions contained a number of provisions designed to ease the transition to gold. These included the recommendation, ultimately adopted, that governments with significantly depreciated currencies 
consider statilizing at a lower rate of exchange. While accepting the argument that premar parities provided the ideal basis for stabilization, the experts suggested thet countries which had experienced sustained inflation might be well advised to avoid the output costs associated with restoring the prewar level of prices. Moreover, they observed that governments would be seriously burdened by the increased real value of internal debt which would result from a substantial reduction in prices. 32 Policymakers were therefore encouraged to stabilize at rates not far distant from thase currently prevailing. Significantly for the operation of the interwar gold standard, no sanctions were included to discourage governments from engaging in competitive depreciation.

The Genoa resolutions also contained proposals to economize on the use of gold. The measures proposed by the Cunliffe Comittee were altered to meet what the British experts regarded as mounting deflationary pressures. Fiesolution 9 on currency adopted by the financial commission urged governments to establish a mechanism to minimize the need for gold by "maintaining reserves in the form of foreign balances, such as the gold Euchange standard, or an international clearing system."

It was in this connection that the issue of policy coordination was raised. Monetary authorities were encouraged to coordinate their deflands for gold and to avoid the wide fluctuations in internal prices that would otherwise result from the "simultaneous and competitive efforts of a number of countries to secure metallic reserves." 33 Thus, central banks were for the first time explicitly urged to desist from the competitive struggle for gold. These proposals for international cooperation were predicated upon the establishment of central banks where they did not exist and on their insulation from political influence or control. Thus, at Genoa 
countries with relatively stable currencies were therefore urged to adopt institutional arrangements similar to those imposed by the League of Nations upon countries undergoing hyperinflation.

The only resolution on international policy coordination acceptable to all the participating countries was one couched in general terms. While consultation and collaboration were encouraged, no formal mechanism for their practice was specified. Instead, the Bank of England was requested to call an early meeting of central bankers to preparg a convention to implement these measures. An accompanying resolution warned that the succese of any such plan was contingent upon the participation of the United States. In the words of the Financial Commission, no scheme for stabilizing prices "can be fully effective without coordination of policy between Europe and the United States, whose cooperation therefore should be invited." 34

There is no question that the economic costs of noncooperative behavior were clearly understood in 1922. Permitting central banks to Engage in a competitive struggle for gold was seen as threatening to transmit deflationary pressures to the world economy and delaying recovery from the war. Multilateral negotiations were seen as the most effective technique for achieving agreement on an acceptable international distribution of reserves. Yet it was far from apparent how agreement on this matter might be reconciled with national autonomy on the question of the level at which to stabilize exchange rates, or how these noble sentiments night be institutionalized. But if the participants in the Genoa Conference lacked a coherent view of how policy coordination might be practiced, they agreed on the principle of responding cooperatively to international financial problems.

Ultimately, even this modest attempt to provide a framework for 
cooperation proved to be overly ambitious. To the surprise of the Farticipants, the next step in the process, namely the proposed meeting of central banks, was never held. The Bank of England took the initiative of discussing the proposed meeting with the federal feserve, whose participation was endorsed by the U.S. State Department. Once the Bank of England's Committee of Treasury approved the tentative invitation drafted by Norman and Eeniamin Strong, a meeting seemed imminent. 35 However, efforts to convene the meeting met with political obstacles, and the prospective conference Has soon reduced to a mere bargaining chip to be used in disputes over these ottier concerns. The French ruled out their participation unless fieparations were again excluded from the agenda. The Americans objected that meaningful progress could not be made unless the Reparations question was reopened. In the autumn of 1922 Eritain sent a delegation to Wastington to discuss funding the Eritish war debt, and the Eank of England s involvement in these regotiations again postponed the meeting of central bankers. France's occupation of the Ruhr in 1923 cast doubt on Germany participation, and the financial difficulties of Austria and Hungary was the occasion for further delay. By the summer of 1923, Enthusiasm for a general convention of central banls had dissipated. This was not to mark the end of financial collaboration, but subsequent exchanges between central banks took place primarily on a bilateral basis. 36

With the failure of the Genoa Conference to yield even a general framework for international policy coordination, nany of the dangers cited by the financial experts quickly came to pass. There were no sanctions to discourage governments from stabilizing at parities which yielded a system of misaligned exchange rates. There was no mechanism for reconciling the 
competing objectives of national monetary authorities nor to prevent central banks from engaging in what was characterized as a competitive scramble for gold. The implications of noncooperative behavior within the framework of the interwar gold standard would become evident soon enough.

\section{Leadership and Cooperation Under the Interwar Gold Standard}

A. Notivation

Establishing a basis for cooperation among central banks was clearly one of the principal goals of the policymakers who attempted to lay the foundation for the gold standard's resurrection. Yet the gold standard is typically portrayed as a self-equilitrating mechanism under which external balance is restored to deficit and surplus countries alike through the smoth operation of an anonymously functioning international adjustment mechanism. The very concept of conflicting objectives, much less strategies such as leadership and cooperation, are wholly incompatible with familiar attempts to model the gold standard's operation. These familiar models are simply incapatile of addressing the questions at hand.

The purpose of this section is therefore to develop an alternative model of the gold standard with which the issues of leadership and cooperation can be addressed. No attempt is made to capture the operation of the international gold standard in all its complexity, for this is not the model's purpose. Its purpose is rather to provide a simple macroeconomic framework which highlights the channels through which the actions of one country's central bank impinge upon the internal and external position of another and the incentives that these repercussion effects provide the second country to respond to the actions of the first. It strips away complications in order to lay bare the dynamics of strategic interaction and to explore the implications of long-standing arguments 
about the benefits of leadership and cooperation during the interwar period.

The model is based on the notion that the interwar gold standard can be viewed as an "international struggle for gold."37 simply put, central banks in our model desire incompatibly large stiares of the world s gold reserves. This provides the basis for conflicting objectives and for strategic interaction.

Despite its simplicity, the model generates several useful insights. As in any strategic game in which the players hold conflicting objectives, noncooperative behavior has economic costs compared with cooperative solutions. 39 In our model, central benks incapable of coordinating their policies set their discount rates at undesirably high levels, putting downward pressure on the level of prices and depressing incomes at home and abroad. For example, this is the result at the Nash solution to this noncooperative game. Hhile central bank policy was but one factor at work in the world economy in the 19205 , this result is suggestive when applied to a period marked by historically high discount rates, conflicts among central banks, and steady deflation culminating in a Great Depression. The Stackelberg leader-follower solution to the two-country model provides a halfway point between the Nash and cooperative equilibria. Compared to the Nash solution, the leader-follower solution is less deflationary and yields higher incomes both at home and abroad. Barring cooperation, the exercise of leadership clearly is in the interest of both players; the question is whether either player will choose to exercise it. In fact, there is an incentive for both players to resist the leadership role. It is a standard (and perfectly intuitive) property of models of symmetrical countries that both players prefer to adopt the sane strategy. We show below that the same holds true in a model of asymmetric countries, 
where one central bank has exceptional power to influence the direction of international capital flows.

In structure the model has much in common with previous analyses of. policy coordination (see for example Hamada, 197t and 1979). It incorporates the assumption that each central bank has more targets than instruments, forcing it to confront the tradeoff between its objectives. This is the assumption of instrument scarcity in whose absence problems of strategy vanish. In addition, it incorporates the assumption that each domestic target variable is affected by the actions of the foreign central bank. This is the assumption of interdependence:

There exists scope for strategic interaction in a model of the gold standard only if central banks can exercise discretion. He will assume that central banks are atle to engage in discretionary initiatives to alter the composition of the fonetary base through open market operations or changes in fiduciary circulation and to affect the size of the money multiplier through changes in discount rates. While the idea that changes in central bank discount rates affect the relationship between the gold reserve and the money supply is a departure from textbook treatments of the gold standard, it captures the fact that the authorities were capable in the short run of either reinforcing the impact of incipient gold flows on domestic financial markets or neutralizing them through sterilization. In fact, under the gold standard there were important sources of slack in the conrection between gold reserves and broadly defined monetary aggregates. Central banks could hold gold in excess of that required to back notes in circulation, enabling them to intervene in financial markets with purchases of bonds and bills and to alter the monetary base without any accompanying change in reserves. Only the need to maintain confidence in the 
convertibility of the currency placed limits on their discretionary actions. Similarly, commercial banks, even if free of statutory reserve requirements, had an incentive to hold precautionary reserves to guard against unanticipated withdrawals. The size of such precautionary reserves was determined in part by the cost of feasible alternatives, including discounting (in the Eritish case, via discount houses) at the central bank. Under the British banking system, there was a conventional ratio between a bank's cash and its liabilities which was basically the same whether those liabilities were demand or time deposits. Nonetheless, the authorities could influence this ratio and hence affect broadly defined monetary aggregates through chäges in the deposit multiplier. 39 This was even more true of the countries of the Continent, where there was typically no converitional or legal relation between reserve assets and deposits.

Each central bank in our model minimizes a quadratic loss function defined over gold reserves and domestic prices. Although the historical record suggeste that central bankers folloned rules of thumb then setting discount rates, we adopt the assumption of optimizing behavior as a simplifying device. The assumption that each bank has an optimal gold reserve is motivated ty the observation that, while a central bank could feel more confident of its ability to defend the convertibility of the currency with a larger gold reserve on hand, it was less profitable to hold barren metal than interest-bearing financial assets. 40

The idea that central banks maintained a target level for prices is another simplifying assumption. Occasionally it is argued that central banks were concerned ultimately with the domestic currency price of gold and that they desired only to prevent such fluctuations in prices and economic activity as night threaten convertibility. Ey this interpretation, the price level is properly viewed not as an independent 
goal of policy but as an intermediate target whose achievement was helpful for attaining the ultimate objective: maintaining convertibility. Yet central banks were under pressure throughout the interwar years to respond actively to internal conditions. The Eritish case provides an illustration of the pressures brought to bear. British central bankers were publicly cautious when relating their policy to the state of the domestic economy. According to Montagu Norman, the Gank of England's interwar Governor, the ill effects of a high Bank Fate on domestic industry and trade were greatly exaggerated and "more psychological than real." 41 of course, by 1930 , when this statement was made, the Eank had been subjected to Treasury criticism for more than half a decade; in 1924, a more relaned time, Norman had expresed concern for the imact of monetary deflation on the state of the economy. ${ }^{42}$ The caution that characterized the Bank's public pronouncements by the end of the decade can be seen as a response to the criticism to which it was subjected. Keynes' articles on monetary policy are the best-known examples of the genre. 43 Surely, however, the Eank of England was more profoundly affected by criticism emanating from H.M. Treasury. The principal goals of Treasury policy in the twenties were to retire outstanding debt and to reduce the burden of debt service charges through conversion of the five percent government loans of 1917 at low interest rates. Debt service had risen from 11 percent of central government spending in 1913 to 24 percent in 1920 and more than 40 percent by the end of the decade. 44 Hence between 1925 and 1929 the Treasury consistently objected to Bank of England initiatives which raised the price and reduced the availability of credit. These objections were often communicated to the Eank directly. For example:

"The Governor of the Eank called at the Treasury on the 2 nd December [1925] about $7: 15 \mathrm{pm}$, and informed me that there 
was every probability that the Rank Rate would be increased ... I reported this to the Chancellor on the following morning and he at once telephoned to the Governor that if the rate were raised, he would have to inform the House that it had been done without his being consulted and against his wishes. It was not fair to the Exchequer that action should be taken which affected all its affairs without an opportunity being given to hin to consider it. He expressed an earnest request that action should be deferred at any rate

Whatever the central bankers beliefs about the effects of monetary policy, it is difficult to dispute that such pressures would have encouraged them to act as if they were concerned about the state of industry and trade. In fact, Bank of England reaction functions for the period 1925-31 indicate come censitivity of discount rate policy to the state of the domestic economy. ${ }^{46}$ In what follows, the target of a stable price level can be thought of as shorthand for stable prices, output and employment and, depending on the reader's interpretation of the historical literature, different weights can be attached to internal and external targets without greatly affecting the results.

E. Specification

Consider a world of two identical countries, home and foreign. 47 We log-linearize all relationships and use lower case letters to denote the logs of the variables represented by the corresponding upper case letters, except for interest rates which are always measured in levels. Each country has a model supply $M$, which can be thought of as an M1 or M2 measure. This aggregate is the product of the monetary base and the money multiplier $V$. The base is made up of domestic credit and the central bank's gold reserves. The domestic credit component of the base can be positive or negative, depending on whether central banks hold excess gold reserves or there is a fiduciary issue outstanding. However, to simplify the model we abstract entirely from the domestic credit component of the 
base. 48

We assume that a rise in the discount rate, by increasing the cost of rediscounting at the central bank, induces the consolidated banking sector to hold a larger ratio of precautionary reserves to liabilities. Hence the money multiplier depends negatively on the central bank discount rate. Using asterisks to indicate foreign variables, we have:

$$
\begin{aligned}
& m_{i}=-v r+h \bar{g} \\
& m_{*}=-v r *+(1-h)_{\bar{g}}
\end{aligned}
$$

where $v$ is the elasticity of the money supply with respect to the discount rater. $\bar{g}$ denotes the log of the world stock of monetary gold, of which shares $h$ and (1-h) are held by the domestic and foreign countries. The demand for real balances is a function of output $Y$ and the narket interest rate i:

$$
\begin{aligned}
& m-p=\phi_{y}-\lambda i \\
& m^{*}-p^{*}=\phi_{y}^{*}-\lambda i *
\end{aligned}
$$

where $p$ and $p^{*}$ denote logs of domestic and foreign prices respectively. Only mathematical complexity is added by assuming that nominal balances are deflated by a consumer price index comprised of domestic and foreign prices. Aggregate supply in each country is an increasing function of producer prices:

$$
\begin{aligned}
& y=y(p)=\hat{y} \quad \tilde{y}, \tilde{y}^{*}>0 \\
& y^{*}=y^{*}(p *)=y^{*} p^{*}
\end{aligned}
$$

where for convenience we assume constant elasticities of supply $\hat{l}^{m}$ and $\left.y^{*}\right)$ and standardize the normal level of output to unity. These functions can be thought of as the short-run supply curves of an aggregation of profit-maximizing firms confronting predetermined wages or material costs. Rather than introducing costs explicitly, we simply note that the classical full employment model $\left\{y^{n}=y^{*}=0\right)$ and the keynesian incone- 
enpenditure model $\left\{\begin{array}{l}y \\ y\end{array}=\ddot{y}-y\right.$ m can be treated as special cases. The short-run tocus of the model should be borne in mind in the discussion that fol10W5.

Aggregate demand depends positively on the relative firice of imports and negatively on the interest rate. The exchange rate is normalized to unity and suppressed.

$$
\begin{aligned}
& d=s(p *-p)-B i \\
& d *=-8(p *-p)-B i *
\end{aligned}
$$

We close the model with the open interest parity condition on the essumption that nonmonetary assets denominated in the two currencies are perfect substitutes and capital is perfectly mobile.

$$
i=i *
$$

The onission of gold production, wealth effects and dynamics of adjustment, to mention but a few complications, is obvious. Nany of these complications could be appended to the model. However, our intent here is not to build a complete model but to present a simple analytical framework containing the essential ingredients for the study of a particular historicel episode.

We now posit an objective function for each country of the form:

$$
U=-\left[(p-\bar{p})^{2}+w(h-\bar{h})^{2}\right]
$$

where $W$ is the weight attached to gold reserves relative to prices, output and employment. 49 we assume $\bar{h}>1 / 2$ to capture the idea that the two countries prefer incompatibly large shares of the (log of the) world's stock of monetary reserves--in other words, that the gold standard can be characterized as a competitive struggle for gold. It will be convenient to normalize $\bar{p}$ to zero. 
To derive a semi-reduced form expression for h, we set each country's money supply equal to its money demand and take the difference of these tho relations.

$$
h=1 /(2 \bar{g})[\bar{g}+v(r-r *)+(1+\phi \hat{y})(p-p *)]
$$

Setting aggregate supply (3) equal to aggregate demand (4) and substituting each country's money supply and money demand equations ( 1 ) and (2)] into its goods market clearing condition yields a semi-reduced form for p:

$$
p=\pi(v / 2(r+r *)-\bar{g} / 2]
$$

where:

$$
\Omega=\frac{-1}{\ddot{y}+\lambda / B(1+\eta y)} \quad-1<\Omega<0
$$

It is evident that this model provides the minimal ingredients for a study of interdependence. The first element we require for an analysis of interdependence is that each central bank faces a tradeoff between its target variables. From (7) and (8):

$$
\frac{3 h}{3 r}=\frac{y}{2}>0 \quad \frac{3 p}{3 r}=\Omega \frac{v}{2}<0
$$

and similarly for the foreign country. A rise in the domestic discount rate increases the domestic money multiplier, putting downward pressure on the price level, and by reducing domestic money supply relative to domestic money demand attracts gold from the foreign country.

The second element we require is that the target variables in the home country are affected by the actions of the foreign central bank. Again from (7) and (8):

$$
\frac{\partial y_{1}}{\partial y^{*}}=\frac{-v}{2}<0 \quad \frac{3 p}{3 x^{*}}=\Omega \frac{v}{2}<0
$$

An increase in the foreign discount rate reduces the foreign money multiplier and the foreign money supply, attracting gold from the home country and depressing the world price level. Analogous results hold for 
the foreign country.

It is worth noting we have here a case of positive international transmission. Initiating an expansionary policy in one country leads to expansion in the other. This result contrasts with the assumption often made about international transmission between the wars: that policy was "beggar-thy-neighbor" in the sense that expansion in one country caused contraction in the other. The contrast is due to the way we model the international monetary regime: in this model of the 1920 s with fixed exchange rates international transmission is positive, while in a comparable model of the 1930 with flexible rates, transmission magt well be riegative.

The choices confronting central banks can be illustrated with two familiar diagrams. From (9), we know that, given r*, the domestic central bank can vary $r$ to attain different combinations of $h$ and $p$. In Figure 1, the frontier of feasible combinations is labelled AA. The optimal setting for $r$ is one which achieves a h-p combination tangent to an indifference curve at the point labelied $F$.

Consider now a rise in $r *$. This shifts the $A A$ frontier inward to A'A'. The home country's central bank, faced with a smaller world money supply, is forced to accept lower prices, smaller gold reserves, or a combination of the two. As drawn, it moves to a point such as g tangent to a less desirable indifference curve where both prices and reserves have fallen.

The same exercises can be conducted for the foreign central bank. The analysis becomes interesting once we combine the two banks problems and consider their interaction. This can be done by transposing the indifference curves to r-r* space as in Figure 2. We read off from figure 1 the home country's rankings of different combinations of the two discount 


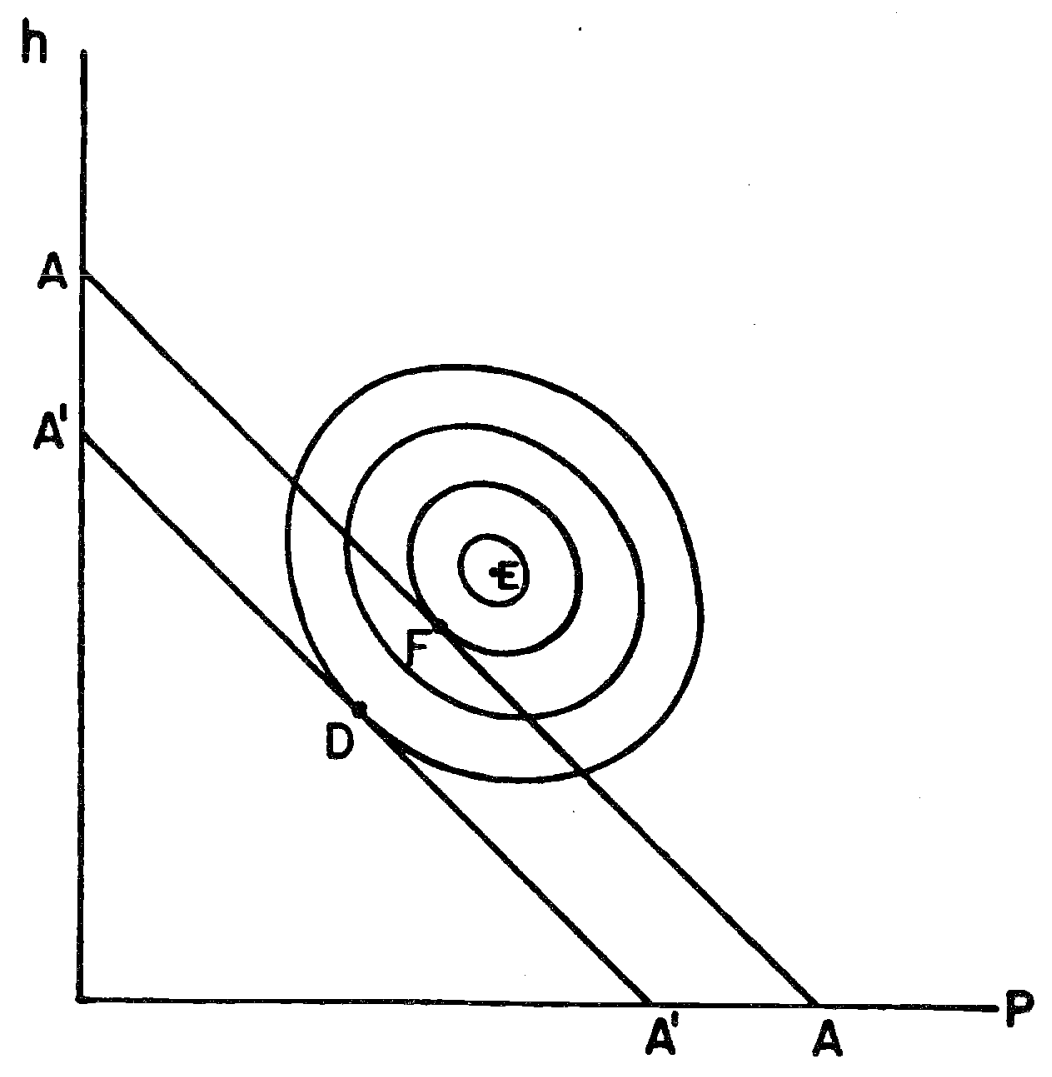

Figure 1 
rates. Thus, point E in figure 2 at the center of the home country's solid indifference curves corresponds to point $E$ in figure 1 . The fact that the foreign central bank's indifference curves lie to the northsest of the home central bank's indifference curves reflects the assumption that the two central benks ideally wish to hold incompatibly large shares of the world's gold stock. This is accomplished when each bank's discount rate is high relative to that of its rival.

The downward sloping pp locus depicts combinations of $r$ and $r$ for which a price level $\vec{p}$ obtains. Along parallel lines below and to the left of pp, frices are higher, while atuve and to the right, prices are lower. With symmetry, the two central banks share a common rank ordering over prices and the pp line has a 5 lope of -45 degrees.

The $F$ and $F$ * curves in Figure 2 are the reaction functions of the two central banks. The f curve, representing loss-minimizing discount rates for the home central bank given the foreign discount rate, is the locus of points where the targent to the home indifference curve is horizontal. Similarly, the $F *$ curve is the locus of points where the tangent to a foreign indifference curve is vertical. The reaction functions may be positively sloped, as in figure 2 , or negatively sloped. The slopes can be derived by substituting the semi-reduced forms for $h$ and $p$ into the objective function, differentiating with respect to each discount rate and setting the solutions to zero:

$$
\begin{aligned}
& \left.\frac{\delta r^{*}}{\delta r}\right|_{\mid F *=0}=\frac{\omega+\delta^{2}}{\omega-\pi^{2}} \\
& \left.\frac{\delta r^{*}}{\delta r}\right|_{\mid F=0}=\frac{\omega+\sigma^{2}}{\omega-\pi^{2}}
\end{aligned}
$$

Both reaction functions will be positively sloped when the weight attached to gold reserves $w$ is large relative to that placed on prices. Then each 


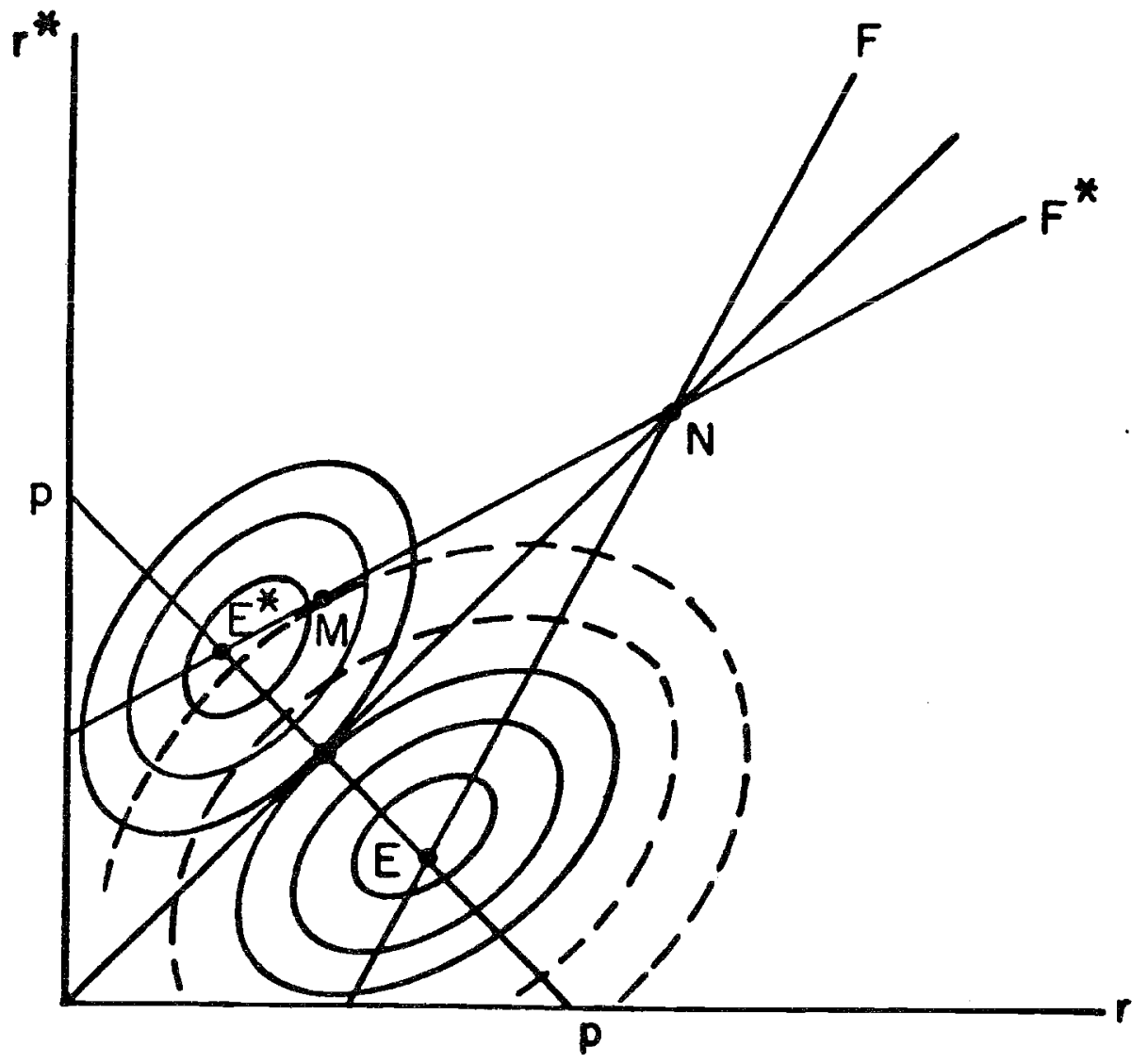

Figure 2 
central bank responds to a foreign discount rate increase by raising its own rate, attempting to stem the loss of gold reserves at the cost of 5 till lower prices. Conversely, both reaction functions will be negatively sloped when the weight put on gold reserves is relatively small. In this case, each country responds to a discount rate increase abroad by lowering its discount rate, attempting to reduce the fall in prices at the cost of still lower gold reserves. So long as stability is maintained las can be shown to obtain under symmetry and under other cases considered belowl, the arialysis is essentially the same.

The discussion to follow will concentrate on the configuration depicted in figure 2. The case of upward-sloping reaction functions, in which each country is inclined to respond to a change in the foreign discount rate in the same direction, appears to be the historically relevant case for the 1920 s.

\section{Solutions}

We can now determine the equilibrium values of $r$ and $r$ under different solution concepts. After discussing the outcome under different assumptions, we will ask the question of which solution is likely to obtain.

First, we consider the model's Nash solution at the intersection of the reaction functions. Note that in the symmetrical model the two discount rates are identical at the Nash solution, so the level of prices and reserves will be the same in each country. In particular, since $p=p$ * at the Nash solution, we can cancel the second additive term in equation (9) when solving for its characteristics. Differentiating the objective function with respect to each discount rate under the assumption that the other discount rate is invariant, setting each solution to zero and 
equating them yields:

$$
r_{N}=r_{N}^{*}=\frac{1}{v}\left[\frac{1}{2} \bar{g}+\frac{\omega}{\Omega^{2}}\left(\bar{h}-\frac{1}{2}\right)\right]
$$

where the $N$ subscript denotes the Nash solution.

Second, we consider the cooperative solution. Under symetry, each country holds exactly half the world's monetary gold, and prices are again identical in the two countries. The best they can then do is to set their discount rate equal to one another at the level consistent with $p=0$. Setting (9) equal to zero yields:

$$
r_{C}=r_{C}^{*}=\frac{1}{2 v} \bar{g}
$$

where the C subscript denotes the cooperative solution. From (13) and (14), $r_{N}>r_{C} 50$ long as $\bar{h} \geqslant 1 / 2$.

Under symmetry, the Nash and cooperative solutions yield identical distributions of gold. However, under the assumption of Nash behavior, the desire of rival banls to possese incompatibly large shares of the world's gold stock cause both banks to elevate their discount rates above the level consistent with price level p. Each is subject ot the misapprehersion that a marginal increase in its discount rate will secure it larger gold reserves at the cost of a relatively small decline in prices. In fact, each discount rate increase elicits an increase in the foreign discount rate, yielding the initiating bank no additional gold reserves but resulting in still lower prices. Thus, the strategic interaction of central banks imparts a deflationary bias to the world eccnomig, given only the assumption that $\bar{h}>1 / 2$.

Finally, we consider the case where the home country acts as Stackelberg leader and the foreign country follows. Substituting the foreign country's reaction function into the home country's objective function and minimizing the loss yields the solution depicted at point M in Figure 2, where a home indifference curve is tangent to the foreign 
reaction function. The home country's central bank recognizes that if it lowers its discount rate the foreign central bank will respond in kind. Herice, it is aware that the loss of gold reserves brought about by its dascout rate reduction will be partially offset by the reduction in the foreign discount rate, and that the response of the foreign central bank will yield further benefits by reinforcing the tendency of lower discount rates to raise the world money supply and price level. The leader-follower strategy yields a lower domestic discount rate than the Nash solution, resulting in a tigher level of utility for the domestic country, whose loss of gold is more than offet by higher prices, output and employment. The foreign central tank benefits on both counts, since prices are higher and it now ottains a larger share of the world's gold stock. 50

In this model, the strategic interaction of central banks imparts a deflationary bias to the world economy, assuming only that at the optimum they desire incompatitly large shares of the world's gold stock. Leaderstip tas advantages over other noncooperative strategies: a country which tales its foreign rival's reaction into account can initiate a reduction in discount rates, raising prices and stimulating activity at home and atroad. Cooperation has further advantages over leadership: through cooperation both discount rates can be lowered and the deflationary bias in monetary policy can be eliminated.

\section{Eustainatle Strategies}

To this point we have not addressed the question of which solution is likely to obtain. In this section we first consider this question using the symmetrical model of previous sections which is intended to represent the strategic interaction of two or more comparable financial centers during the interwar years. We then extend the analysis to a simple 
asymetrical case intended to capture aspects of the prewar situation. Assuming that cooperative strategies are not feasible, is the Nash solution or the stackelberg leader-follower solution lilely to obtain? He have noted that both countries benefit with movement from the Nash solution to the leader-follower solution. It is clear also that with upward-sloping reaction functions the follower reaps the greater gains: while both countries tenefit from higher prices, only the follower benefits from a larger gold reserve. In Figure 2 , the gains from discount rate reductions are evenly distributed among countries as they move down the 45 degree line toward the origin. Since the leader-follower solution is on the follower 5 side of that line, the leader reaps the smaller benefits. As Cooper (19g4) suggests, the fact that the follower reaps the larger benefits encourages both parties to engage in a game of "chicken," each attempting to force the other to accept the role of leader. There nay be extended periods when the Nash solution is observed as this game of "chicken" is being played out. Clearly this is one way to interpret statements to the effect that the interwar monetary system was characterized by the absence of leadership. We might attempt to capture the change in structure of interrational financial markets between the end of the 19th century and the interwar period by adding to the model an asymetry in the ability of discount rates to influence international capital flows. Assume that the discount rate of the domestic central bank iwhich fight be thought of as the gank of England) has a larger impact than the foreign discount rate on the donestic money supply (i.e., that $\psi *=\theta v$ where $0<\theta<1)$. In all other respects, jncluding objective furctions, the two countries remain the 5 ame. since from $(9)$ and $(10)$ dh $/ d r_{i}=-v_{i} / 2$, the domestic discount rate has a larger impact than the foreign discount rate on the international distribution of gold. 
Strikingly, introducing this asymmetry into the model does not alter the fact that, in the case of positively-sloped reaction functions, each country prefers its foreign counterpart to play the stackelberg leader. The intuition is straightforward. For simplicity of exposition, consider the case where $v$ is unchenged from sub-sections $B$ and $C$ above but $v *$ is now smaller. Since $v^{*}=\theta v^{*}$ we can rewrite equation (1) for the foreign country a5:

$$
m^{*}=-v \theta r *+(1-h) \bar{g}
$$

and leave the rest of the model unchanged. In this case, the model arid its solutions are the same, except we can think of the foreign central bank as setting and the domestic central bank as reacting to er* rather than $r *$. At each solution, the domestic discount rate is the same as in the symmetrical case, while the foreign discount rate is simply $\theta$ times its value in the symmetric model. In $r$ - $\theta$ r* space, the various solutions could be depicted by the symmetrical diagram of figure 2. In r-r* space, the Slope of each reaction function would have to be multiplied by $1 / \theta$. All of the conclusions from the symetric model concerning the gains to Stackelberg leaders and followers continue to hold.

The simple asymetrical model suggests, therefore, that to the extent that the Eank of England had more power than its foreign counterparts over the direction of gold flows, this would not have encouraged it to exercise leadership in the stackelberg sense. If asymmetries in economic structure are to provide an explatiation for the Gank of England's leadership role, they must be more subtle than the simple asymetry considered here.

IV. The Tripartite Monetary Agreement of 1936 and the Role for Cooperation The devaluation of sterling in 1931 marked the end of the truly international gold standard of the interwar years. The Bant of England had 
succeeded in holding sterling between the gold points during the period 1925-1930 only under consideratle duress. The onset of the Great Depression then placed a downward pressure on prices, pushed the government budget into deficit and by the summer of 1931 raised unemployment rates to 20 percent of the insured labor force. Following financial crises in Austria and Germany and with the Labour and National Government's inability to take convincing steps ejther to talance the budget or to initiate economic recovery, defense of the sterling parity was abandoried in September. Against the dollar and the currencies of other countries that continued to peg to gold, the pound depreciated by 25 percent, from 4.86 to $\$ 3.75$ at the end of the first week of floating.

More than two dozen countries allowed their currencies to depreciate with sterling, among them most of the Empire, Scandinavia, and Eastern Europe. 51 Germany for its part adopted draconian exchange controls and moved increasingly toward a system of bilateral clearing arrangements with its Eastern European trading partners.

The United States troke with gold in 1933. In March Roosevelt restricted foreign exchange dealings and gold and currency movements, and in April he issued an executive order requiring individuals to deliver their gold coin, bullion and certificates to Federal Reserve Banks. At this point, the dollar began to flaat. Ey setting a series of progressively higher dollar prices for gold, the Administration engineered a significant devaluation. The dollar was finally stabilized in January 1034 at $\$ 35$ an ounce, 59 percent of its former gold content. The only major currencies that remained freely convertible were those of the Gold gloc countries: France, Belgium, Holland, Italy, Poland and Switzerland. These countries were willing to go to great lengths to defend 
their established parities.

Thus, the international monetary system of the mid-1930s was a hybrid of different regimes. Eritain was engaged in a managed float administered by the Exchange Equalization Account (EEA). The United States in January 1934 pegged the dollar to gold at the new $\$ 35$ price but extended convertibility only to countries on the gold standard. France, under the provisions of the monetary law of 1928, was fully on the gold standard and obligated to buy and Eell gold without limit at the prevailing price.

As late as the summer of 1936 the official goal of French policy was to defend and maintain the franc Poincarte. Despite the déptith of the Eepression, the Eant of France continued to respond to gold losses by raising its discount rate. Belgium's devaluation in 1935 served to signal the extent of the franc 5 overvaluation, and confidence was further undermined by political developments abroad, including Italy's invasion of Ethiopia, Germany's occupation of the Rhineland, and the outbreak of the Spanish Civil War. With the formation of Leon Blum's Popular Front Government in April 1930 , pressure on the franc intensified. Blum was pledged to stimulate domestic activity while at the same time maintaining the gold standard parity. 52 Market participants were aware of the incompatibility of these objectives. Blum's proposals had included public works and putlic employment, a reduction in the length of the work week, paid holidays, universal collective bargaining, and public control of heavy industry and finance. French labor initiated sit-down strikes soon after the election to induce speedy implementation of these measures, and the Eank of France's gold reserves plummeted as a result of capital outflows. The Eank responded by raising its discount rate to b per cent, three times the Bank of England's rate. Discrete consideration began to be given to the possibility of devaluation. 
As devaluation of the franc came to be seen as probable, French policymalers considered how to capitalize on the situation ard foreign policymakers how to minimize the damage. Yet the French position was not without difficulties. One Frencti objective was to devalue by a margin adequate to secure a competitive advantage--in other words, devaluation on the 19205 model. At the same time, they were constrained by the necessity of not arousing the indignation of the electorate or thejr trading partners. Since the fopular front had come to power committed to the gold standard, it was desirable that devaluation occur as part of a multilateral system of exchange rate adjustments which laid the basis for a general return to gold. Moreover, given the spectre of 1923 and 1926 , the French were concerned that a substantial devaluation might cast doubt on the credibility of any fixed parity and set off a vicious spiral of depreciation. To allay speculation the French therefore proposed that realignment be followed by the establishment of new, more realistic gold staridard parities by the Eank of England, Eank of France and Federal Feserve.

In addition to the domestic political situation, the Popular front had reason to worry atout foreign retaliation. Earlier in the decade, Frarice had imposed new commercial restrictions in response to foreign devaluation, leaving her little diplomatic defense against the adoption of comparable measures by the U.S. and U.K. Equally worrisome was the danger of competitive devaluation. There was no internal code of conduct governing the management of exchange rates. The British EEA could intervene with sales of sterling to push the pound down along with the franc, and if 1033 was any indication the American response might be a further devaluation of the dollar. Hence from the French perspective it was essential before 
proceeding with devaluation to secure an agreement on acceptable margins of adjustment.

For the gritish and Americans, the danger attached to a French devaluation was that it was beggar-thy-neighbor policy. To the extent that London and washington viewed one another as inclined to retaliate against a French devaluation, each feared that its own competitive position would be seriously eroded. Moreover, competitive devaluation would only exacertate exchange-rate instability and uncertainty, with a depressing impact on trade. For the Eritish, the spectre of a French devaluation raised the further possibility that London's complete control over the foreign Exchange value of sterling would be compromised by French intervention directed at other targets.

The U.S. and U.K engaged in sporadic negotiations in the spring of 1935, but to little effect since the Americans were primarily concerned to avoid another round of competitive devaluation while the British were primarily concerned to retain their freedom of action. Following the triumph of the Popular Front in 193t, channels of commuication between the governments were reopened. The U.S. continued to press for multilateral negotiations over acceptable margins of adjustment, while the U.K. was willing to go no further than to express its hope that the dollar-pound rate could be held steady so long as devaluation of the franc was moderate. 53 Blum and his ministers couched any discussion of devaluation in terms of a fundamental restructuring of the international monetary order. In early September the French proposed an agreement among the three governments which would specify new bands for the franc, dollar and pound, commit the three governments to collaborative efforts to maintain those rates, bind them not to devalue except by mutual agreement of under exceptional and unforeseen circumstances, and compel them to 
return to gold convertibility once stability was restored. 54

This ambitious French proposal was coolly received n London and Wastington. The Americans were unwilling to commit to an eventual return to gold or to stabilizing the dollar within a fined band. Treasury Secretary Morgenthau favored only a mechanism for collaboration among the exchange equalization funds of the three countries and working agreements about the management of rates. The British opposed even more strongly any scheme which threatened to limit their freedom of action. 55 British officials hoped only that Blum and his Minister of Finance Vincent Aurol would devalue tre franc in a convincing yet moderate manner, by a margin large enough to induce foreign capital inflows and permit stabilization but small enough to leave unaffected relations between London and Washington. 56

The French response to these objections was to drop their proposal for fined bands but to continue advocating an eventual return to gold. 57 However, the Americans and Eritish continued to object to any mention of the gold standard. Ey the middle of September the French had begun to recognize that the only agreement which might prove acceptable to both London and Hashington was one couched in very general terms. 58 Ariol s neut proposal was for a single deciaration by the three governments pledging to avoid unilateral changes n exchange rates and unnecessary trade restrictions. 5 i The Treasuries and central banks of the three countries were to agree to cooperate in managing the exchange markets either through bilateral consultations or multilateral negotiations. This proved an acceptable formula. However, to hasten their appearance, Morgenthau suggested substituting for a document signed by the three governments the simultaneous issuing of separate statements once reference 
to the particularly contentious issues had been removed.

With all reference to the gold standard and fixed parities

eliminated, the Tripartite Declarations, much like the resolutions adopted at Genoa in 1922, amounted basically to three simultaneous statements of willingness to engage in consultations among Treasuries and central banks. 60 No formal mechanism for actually coorbinating policies was specified in the documents. Nevertheless, these declarations were seen as essential to insure that the new level for the french franc would be deferisitle. Otferwise, competitive devaluations would be anticipated by the market and create anticipations of a further devaluation of the franc. In return for extending this expression of cooperation so desired by the French, the Americans and British hoped that they might be able to influence france's chaice of parity and prevent an excessive devaluation. Immediately upon the French devaluation of slightly more than 25 percent and release of the declarations, continuous cooperation among the exchange equalization funds and central banks of the three countries commenced. Gelgium embraced the principles of the agreement one day later, and the Dutch and Swiss governments joined within a month. The agreement Was tiailed by the prese. As the New York Times put it, "A streak of sunlight had troken through the dark clouds of nationalismi International cooperation was still possible." 61

In contrast to the aftermath of the Genoa Conference, specific arrangements for day-to-day collaboration followed within a month. Under the provisions of the Gold Agreement Act of October 1936, exchange rates were agreed to daily and the three exchange funds cooperated in market intervention, deciding on a common currency to be bought or sold and settling accounts daily in gold. 62 In this respect, the contrast with 1922 was striking. Part of the explanation for the successful 
Implementation of the Tripartite Agreement lies in the fact that by 1936 the major political obstacles to collaboration--notably Reparations and war debts-had largely receded from view. At least as important, however, was explicit recognition that the range of issues subject to collaboration would be circuiscribed and that nothing in the agreement threatened to undermine each qovernment s independence to formulate domestic policy.

The Tripartite Declarations had warned that although "in their policy toward international monetary relations [qovernments] must take into full account the requirements of internal prosperity, the constant otject of their policy is to maintain the greatest possible equilibrium in the system of international exchange and avoid to the utmost extent the creation of any disturbance by domestic monetary action."63 From this statement it might appear that priority was attached to international policy coordination. In fact, however, internal balance was explicitly recognized as the paramount goal of policy, and the maintenance of international stability was basically a useful ancillary target. As Eeyen $(1949,0.112)$ suggests, policy coordination was seen not as a positive objective of policy but as a negative promise not to indulge in initiatjues that might be overly disruptive to the international monetary system.

The international monetary order that emerged from the Tripartite Agreement placed great emphasis on consultation, but beyond efforts to coordinate day-to-day management of the markets placed few restraints on independent action. It provided no mechanism for the formal coordination of monetary or fiscal policies. Nothing in either agreement bound the participating countries to set their exchange rates at current levels. However, under the new arrangement the dollar began to emerge as the link between gold and other currencies, a position it was to hold for more than 
two decades following the Second Horld War. The U.S. was by no means bound to. stabilize its currency at $\$ 35$ to an ounce of gold, a price which could be changed on 24 hours notice. Eut with the passage of time the Administration grew increasingly attached to this rate. With the dollar fined but adjustable in terms of gold and ether currencies adjustable at the beginning of each day in terms of the dollar, the system resembled a hytrid of Eretton Woods in terms of the relation between gold and the dollar) and a crawling peg (in terms of the relationstip tetween the dollar and other currencies).

Ey the end of 1036 , many of the recommendations put forward at Genoa in 1922 had been implemented but, ironically, at the expense of exchange rate stability. Consultation among governments and central tants, so strongly recommended at Genoa, had been institutionalized under the Frovisions of the Gold figreenent Act of october. Consultation extended however only to day-to-day management of exchange markets, national governments retalning complete discretion to set their external rates. The dollar-sterling rate was effectively pegged within a nerrow band from the French devaluation in 1936 until the second half of 1939 , but the French engaged in several substantial devaluations in the second half of 1937 and again in 1938 . The gold economy measures urged at Genod appeared in the form of restrictions on the internal circulation of gold coin and bullion and measures to limit international flows to transactions between central banks and stabilization funds. With the emergence of currency areas centered upon New York, London and, to a lesser extent, Paris, the reserve currency arrangement proposed at Genoa increasingly became a reality. Indeed, to the extent that the dollar was the currency most tightly linked to gold, it began to exhibit features of the unique role as an international reserve currency it was to take on after World war II. 
The role for policy coordination lay in lending a semblance of order to the currency markets, insuring that retention of a link for gold was consistent with an adequate level of reserves, and discouraging beggar-thy-neightor policy. The role for exchange rate flexitility was to provide governments with independence of action. We will never know how long this systef would have succeeded in reconciling these objectives.

\section{Conclusion}

The interwar period witnessed experiments with every modern international moretary arrangement: clean floating in the first half of the twenties and a gold exchange standard in the second, managed floating in the early 1930s, and after 1936 the reintroduction of a link with gold and a form of adjustatle peg. Whether the regime was based loosely on a system of rules, as in the case of the gold standard, or placed few limits on the discretion of the authorities, as in the case of floating exchange rates, policymaters harbored no illusions that the international monetary arrangenent allewated the problem of interdependence. In each instance they sought to insure exchange-rate and balance-of-payments stability by establishing a framenork conducive to international policy coordination.

A desire for policy coordination is by itself insufficient to insure successful collaboration. The aftermath of the Genoa conference, when political obstacles impeded efforts to arrange a convention of central bants, illustrates the pitfalls to successful implementation. Ultimately, governments turned to noncooperative strategies within the framework of the gold-exchange standard. The competitive struggle for gold and the deflationary pressures that resulted indicated elearly the advantages of cooperation. Therefore, when France's devaluation in 1936 erased the last vestiges of the interwar gold standard, policymakers once more attempted to 
Establish a frameworl for coordinated action. On this occasion, not only was the political situation opporture, but in contrast to earlier efforts the negotiators carefully circumscribed the range of issues subject to collaboration and placed relatively few restrictions on each government s freedom of action. Hence the successful conclusions of the Tripartite Agreement and the Gold Agreement Act.

What energes clearly from this andysis of the interwar period is the tension which pervades all efforts to coordinate economic policies--a tension which is certainly evident also in the 1980s. Then as now the problefi for monetary coordination was how to reconcile the need for freedom of action with the desire for order in foreign exchange markets and with the recognition that national policies have international repercussions. Then as now the institutional response was a hyorid international monetary system combining arrangements for exchange market managenent with autonomy of riational policy, and placing a premium on international policy coordination without providing a mechanism for bringing it about. 
1. For example, according to Eeyen $(1949, p .28)$, "Under a fully automatic standard," by which he means the prewar gold standard, "the need for consultation between central banks was, of course, limited." He tells a story which illustrates central bankers attitudes toward policy coordination and consultation. It seens to have been the tradition at the Netherlands Eank for the President and the Directors to personally count the bank notes withdrawn from circulation at a meeting held directly after lunch. One day in 1912 or 1913 two Directors of the Reichsbank paid a visit to Amsterdam, and the President of the Eank had the novel idea of taling them to lunch. The corversation was "highly interesting, "and the President arrived at the bank note meeting fifteen minutes late with what he thought was an adequate excuse. The oldest of the Directors was unappeased and commented, "Your work is here, not in coffeehouses."

2. Of course, parallel movements in discount rates could be consistent with the rules of the game if all of the countries considered are either gaining or losing gold to some other country not included in the discount rate comparison. See the discussions in Eloomfield (195\%), Horgenstern (1959) and Triffin (1964).

3. For the period of the classical gold standard (18g0-1914), Eloomfield (1959) calculates that central banks complied with the rules of the game only 34 per cent of the time. Even the Eank of England, thought to be invested with special responsibility for managing the system, adhered to the rules only 47 per cent of the time.

4. For example, see the discussions of Eank of England - Eank of France loans in Clapham (1944), volume 2 , pp. $329-392$ and Sayers (1936), Ch. 5.

5. The trans-Atlantic telephone was still used sparingly between the wars. The 1930 interchange between Morganthau and Cochran reported by Clarke (1977) provides an idea of why.

6. Moggridge (1972), Ch. 3. Thus, for example, in Novenber 1921 the three Scandinavian central banks informed the gank of England that, however desirous they were of returning to gold, they felt unable to commit to a parity against gold and the dollar unless the U.k. did so first. The Americans were aware of the problem; since Montagu Norman immediately sent a copy of the confidential Scandinavian memorandum to Eenjamin Strong, Governor of the Federal Reserve Bank of New York. It is not surprising, then, that New York saw Eritain's return to gold as a joint operation. Clay (1957), pp. 141-142.

7. A comprehensive analysis would consider also the World Economic Conference held in London in 1933. See Traynor (1949).

8. United Nations $(1949), p .2$. International comparisons are provided by Edelstein (1981).

9. On the composition of international reserves before 1914, see Lindert (1969). 
10. A typical statement of this conventional wisdom can be found in cleveland (1976), p. 17. As keynes nostalgically described the prewar system from his vantage point in 1930 :

"In the latter half of the 19th century, the influence of London on credit conditionis throughout the world was so predominant that the Eank of England could almost have claimed to te the conductor of the international orchestra. By modifying the terms on which she was prepared to lend... she could to a large extent determine the credit conditions prevaibing elsewhere." keyries $(1930)$, p. 274.

11. Macmillan Comittee euidence of Sir Ernest Harvey, Ouestion 7515, 2 July 1930 , reprinted in Sayers (1976), volume 3, p. 205.

12. Committee on Finance and Industry (1931), p. 125.

13. See especially Triffin (1964) and the sympathetic discussion in ford (1962).

14. It has proven difficult to extract from the historical record convincing evidence in support of this theory. Attempts to plot the U.k.'s terms of trade against levels or first differences in Eank Rate have generally proven inconclusive. See Moggridge (1972), pp. 12-13; Kenen (19t0), p. bo; Lindert (1969), p. 44. Moreover, a number of observers of the London money market lMoggridge, 1972; Brown, 1940) have argued that the valume of commercial bills discounted to finance inventory carrying costs was insensitive to interest rate movements. Hence we make no attempt to incorporate this potential asymetry into the model developed below.

15. Costigniola $(1977), p .1914$ and passim; see also Farrini $\{1969)$.

16. Trade statistics can be found in Loveday (1931), p. 153. Current account estimates are by the Bank of England from Sayers (197t), vol. 3, pp. 312313.

17. Bouvier (1981), pp. 5-6.

18. Keynes (1931), p. 211; Macmillan Committee evidence of Sir Ernest Harvey. Question $7515,2 \mathrm{July} 1030$, reprinted in Sayers (1976), volume 3, p. 205.

19. League of Nations $(1931), p .17$; Svennilson $(1954), p p=233-246$.

20. Moulton and Pasvolsky (1932), p. 431.

21. For monthly statistics, see International Conference of Economic Services (1934).

22. For details, see Bergmann (1927).

23. The classic references are of course keynes (1931) and ohlin (1929). Recent discussions include Maier (1976) and Silverman (1982).

24. Public Record Office (PFO) T160/5, "Export of Gold to America," by R. G. Hawtrey, 5 March 1923.

25. Certain accounts attribute great foresight to the British, suggesting that 
their enthusiasm for the gold-exchange standard was part of a conscious strategy of relaxing Eritain's balance of payments constraint, rejuvenating the city of London, and enhancing the Eank of England's control over international markets. See Costigniola $\{1977)$, p. 917.

26. Costigniola (1977), p. 916, Traynor (1949), F. 72.

27. Archives of the French Ministry of Foreign Affairs (Min. Aff. Etr.) B82/112, "Feunion Interministrielle au sujet de L'Equitable Traitement du Commerce," 28 January 1922.

28. See the interchange of memoranda between the French and British governments in United kingdon (1922).

29. PFO T160/5, "The Genoa Currency Resolutions," by R. G. Hahtrey, 4 February 1922. See also Hawtrey 19231 .

30. See First Interim Report of Committee on Currency and Foreign Exchanges After the Har (1918).

31. The various drafts can be found in United kingdom (1924), p. 59-63. The resolution of the Financial Commission and the Experts. Feport appear in

Mills (1923).

32. To quote the Report of the Committee of Experts, "The question of devaluation is one which must be decided upon by each country according to its view of its own special requirements. We think it important however to draw attention to some of the considerations which will necessarily weigh with any country in coming to a decision on this question. There is a prevalent belief that a return to pre-war gold parity is necessary or desirable for its own sake. There are undoubtedly advantages to be obtained by such a return, but we desire to point out that for countries where currency has fallen very far below the pre-war parity, a return to it must involve social and economic dislocation attendant upon continuing readjustment of money-wages and prices, and a continual increase in the burden of internal debt. Regard being had to the very large debts which have been incurred since the Armistice by many of the countries concerned, we are inclined to think that a return to the old gold parity involves too heavy a strain upon production. We repeat that the decision must be left in each case to the country concerned..." Mills (1923), p. 369. The French were less enthusiastic than the British about endorsing the option of devaluation, pertias due to the franc's weakness and the impact of such a position on confidence. They supported devaluation only for cases where it was demonstrably "impossible" to return to the prewar parity. Min. Fin. Etr. B 82-16/121, Conference Financiere, 11 April 1922.

33. Resolution 9 , reprinted in Mills $(1923), p .36 \%$.

34. Ibid, Fesolution 10 .

35. Clay $(1957)$, p. 158

36. There were notable exceptions to this rule, such as the meeting held on Long Island in 1927 among representatives of four major central banks. See Eichengreen (1984). 
37. The phrase comes from the interchange between keynes and Norman before the Macmillan Committee. See Ouestion 3490 , reprinted in Sayers (1976), volume 3, p. 185. This idea was then adopted in much of the subsequent literature. For example, Cassel (193t, p. 13) remarks "usually, however, the central banks themselves are responsible for the injurous increase in the demand for gold insofar as they compete with one another in their endeavors to strengthen their reserve."

38. This ranking necessarily holds only when all the players contribute to the cooperative solution. Thus, for example, cooperation between governments can be welfare reducing in the absence of cooperation between a government and the private sector. Fogoff (19g3) provides an example of such an outcome.

39. Eritish conventions regarding reserve ratios are discussed by Beyen (1949), PF. 62-63. See also Ealogh (1947). Cairncross and Eichengreen (1983) provide evidence for Britain on the links between the discount rate and the money multiplier. See especially Table Aj.1.

40. The Gank of England and the Eank of France remained privately held institutions influenced still by the desire to pay customary dividends to shareholders. While the extent to which the profit motive and public service figured in the authorities' calculations remains difficult to discern, incorporating the profit motive into models of central bank befiavior is a $\equiv t e p$ in the direction of realism.

41. See Norman s Macmillan Committee evidence: Committee on Finance and Industry (1931), Questions 3328-3517, 26 March 1930, reprinted in Sayers $(1976)$, volume 3, pp. 12-253.

42. For example, see Norman's statements to the Chamberlain-Eradbury Committee in the summer of 1924 , cited in Moggridge $(1969)$, Ch. 2.

43. Formal statements of keynes view of the relationship of monetary policy to the state of trade appear in keynes (1930), while his efforts at pamphleteering are collected in Keynes (1931). Keynes most accessible account of the channels of transmission came in his private evidence to the Macmillan Committee. See Keynes (1981).

44. See Eichengreen and Giavazzi (1984).

45. PRO T176/13, Leith-Ross Memorandum, 3 December 1925.

46. See Eichengreen, Watson and Grossman (1985).

47. Extending the model to more than two countries adds generality but alters none of the conclusions presented below. See Eichengreen (1984), Appendix B, where a simple three-country model is analyzed. Note also that some implications of relaxing the assumption of identical countries are explored below.

48. The model is readily adapted to the analysis of open market operations, and many of the same conclusions follow. Again, see Eichengreen (1984). An advantage of adding the domestic credit component of the monetary base to 
the model is that it would permit domestic assets denominated in one country's currency to be held as international reserves by the other. Again, this adds realism to the model but alters none of the conclusions presented below.

49. This formulation, which places the stock of reserves in the authorities. objective function, is in contrast to most previous specifications of policy coordination problems, which typically assume that the authorities have a target balance of payments surplus ij.e., a target for the flow change in reserves). As Niehans (1968) points out, the specification here would appear to make more eense in a utility-maximizing framework.

50. In the case of negatively sloped reaction functions, the details and implications differ. The domestic central bank realizes that a rise in its discount rate will elicit a reduction in the foreign discount rate, since the foreign country attaches great weight to the stability of prices. The home country's gain from increased reserves more than offsets any loss due to lower prices. In contrast, the foreign country is worse off and unwilling to play the follower. Since both countries prefer to lead, the configuration will be unstable.

51. Hence the movement of the effective exchange rate was somewhat less pronounced; see Redmond $(1990)$.

52. Opposition on the Left to the option of devaluation was based on a recognition that devaluation would only work by reducing real wages, a result which was viewed as unacceptable. Sauvy (1994), volume 1, p. 246.

53. On the reopening of negotiations, see Sauvy (1984), vol. 1, p. 270. On the different national objectives, see Clarke (1977), p. 25.

54. Clarke $(1977)$, p. 34.

55. This is precisely the way they put it to the French. Archives of the French Ministry of Finance (Min. Fin.) B32325, Letter from the Chancellor of the Exchequer, 14 September 1936. Another Eritish concern, sometimes now heard in connection with the European Monetary System, was that the establishment of fixed bands for exchange rates would strengthen the position of speculators by increasing the likelihood of adjustments in one direction, and thereby increase rather than diminish speculative pressures. See Clarke $(1977)$, p. 36.

56. Drummond (1979), p. 9.

57. Min. Fin. B32325, "Projet des note aux gouvernements Americain et Britannique," 8 september 1936.

58. PRO T177/31 "Sir Warren Fisher for Mr. Morgenthau," 14 September 1936, in Telegraphic Correspondence Respecting the Devaluation of the Franc.

Printed for the Foreign office, September 1936.

59. "Secretary of State to Chancellor of the Exchequer," 20 September 1936, in ibid.

60. For the text of the three declarations, see gank for International 
Settlements (1937).

61. "Kestoring Monetary Order," New York Times, 4 October 1936.

62. The exchange funds informed one another each morning of the currency in which they proposed to deal. If the other parties agreed to the currency and the rates, a gold price was specified at which each central bank would exchange foreign currency for gold at the close of the business day. This price was subject to change at the beginning of the next trading day. See FRO T177/33, "Cypher Telegram to Mr. Mallet (Washington)," 7 October 1936.

63. See Bank for International Settlements (1937). 


\section{Beferenices}

Ealogh, Thomas $(1947)$, Studies in Financial Organization, Cambridge: National Institute of Economic and Social Research.

Bank for International Settlements (1937), The Tripartite Agreement of September 25, 1936 and Subsequent Monetary Arrangements, Basel: 815. Mifflin.

Eergmanin, Carl (1927), The History of Reparatione, Eoston: Houghton

Eeyen, J.W. (1949), Money in a Maelstrom, London: Macmillan.

Eloomfield, Arthur (1959), Monetary Policy Under the International Gold Standard, 1980-1914, New York: Federal Reserve Eank of New York.

Eouvier, Jean (1981), "A Fropos de la Strategie D'Encaisse (or et devises) de la Hanque de France de 1928 a 1932, "University of Paris-1, unpublished.

Brown, W.A. (1940), The International Gold Standard Reinterereted, New York: National Bureau of Economic Fesearch.

Cairncross, Alec and Earry Eichengreen (1993), Sterling in Decline: The Devaluations of 1931,1949 and 1967 , Oxford: Easil Elackwell.

Claphafi, J.A. (1941), The Bank of Enqland, Cambridge, Cambridge University Press.

Clarke, 5.4.0. (1967), Central Bank Cooperation, 1924-1931, New York: Federal Reserve Bank of New York.

(1973), "The Reconstruction of the International Monetary System: The Attempts of 1922 and 1933, "Princeton Studies in International Finiarice No. 33 .

(1977), "Eychange-Rate Stabilization in the Mid-19305: Negotiating the Tripartite Agreement, "Princeton Studies in International Finance Ho. 41.

Clay, Henry (1957), Lord Norman, London: Macmillan.

Cleveland, Harold van B. (1976), "The International Monetary System in the Interwar Feriod," in Benjamin Rowland (Ed.), Ealance of Fower or Hegemony: The Interwar Monetary System, New York: New York University Press.

Committee on Currency and Foreign Exchanges After the War (1918), First Interifi Report, Co. 9182, London: HMSO. HMSO.

Committee on Finance and Industry (1931), Report, Cmd. 3897, London: 
Cooper, Richard N. (1984), "Economic Interdependence and the Coordination of Economic Policies," Harvard Institute of Economic Research Discussion Paper, forthcoming in Feter B. Kenen (ed.), Handtook of International Economics, Amsterdam: North Holland.

Costigniola, Frank (1977), "Anglo-American Financial Rivalry in the 19205," Journal of Economic History 37, pp. 911-934.

Eichengreen, Barry (1991), "Sterling and the Tariff, 1929-32," Princeton Studies in International Finance No. 48.

(1984), "Central Bank Cooperation Under the Interwar Gold Etandard," Explorations in Economic History 21, t4-87.

Eichengreen, Earry and Francesco Giavazi (1984), "Inflation, Consolidation or Capital Levy? European Debt Management in the 1920s," Harvard University and University of Venice, unpublished.

Eichengreen, Barry, Mark W. Watson and Fichard Grossman (1985), "Bank Rate Policy Under the Interwar Gold Standard: A Dynamic Probit Model;" (fortheoming).

Ford, Alec (1962), The Gold Standard: Eritain and Argentina, Oxford: Clarendan Fress.

Gayer, A.D. (1937), Monetary Policy and Economic Stabilization, London: Black.

Hamada, K. (1976), "A Strategic Analysis of Monetary Interdependence," Journal of Political Economy $84, \mathrm{pp} .677-700$.

(1979), "Macroeconomic Coordination and Strategy Under Alternative Exchange Rates," in Rudiger Dornbusch and Jacob A. Frankel (Eds.) International Economic Folicy: Theory and Evidence, Ealtimore: Johns Hopkins University Press. GrEen.

Hawtrey, Ralph G. (1923), Monetary Reconstruction, London: Longmans,

International Conference of Economic Services (1934), International Abstract of Economic Statistics, The Hague: ICES.

Kenen, Feter 8. (1960), Gritish Monetary Folicy and the Balance of Fayments, Cambrioge, Massachusetts: Harvard University Press.

Keynes, John Maynard (1930), A Treatise on Money, London: Macilillan. (1931), Essays in Persuasion, London: Macaillan.

(1981), Activities, 1929-1931: Rethinking Employment and Unemployment Policies, in Donald Moggridge (Ed.), The Collected uritings of John Maynard Keynes, Vol. $x x$, Cambridge: Macmillan and Cambridge University Press for the Royal Economic Society.

League of Nations (1931), Course and Phases of the World Economic 
Depression, Geneva: League of Nations.

Lindert, Peter (1969), "Key Currencies and Gold, 1900-1913," Princeton Studies In International Finance No. 24.

Loveday, A. (1931), Gritain and World Trade, London: Longmans, Green.

Maier, Charles (197t), Fecasting Eourgeois Europe, Frinceton:

Princeton University Press.

Mills, J. Saxon (1922), The Genda Conference, New York: Dutton.

Moggridge, Donald E. (1959), The Feturn to Gold, 1925, Cambridge: Cambridge University Press.

Moggridge, Donald E. (1972), Eritish Monetary Policy, 1924-1931, Cambridge: Cambridge University Press.

Morgenstern, 0skar (1959), International Financial Transactions and Business Cvcles, Princeton: Princeton University Fress.

Moulton, H.G. and Leo Pasvolsky (1932), War Detts and World Prosperity, Washington, D.C.: The Brookings Institution.

Nevin, Edward (1955), The Mechanism of Cheap Money, Cardiff: University of Wales Press.

Niehans, Jurg (1968), "Monetary and Fiscal Folicies in Open Economies Under Fixed Exchange Rates: An optinizing Approach, "Journal of Political Economy $76, \mathrm{pp}$. 893-920.

Ohlin, Eertil (1929), "The Reparation Froblem: A Discussion," Economic Journal 39, pp.172-178.

Parrini, Carl P. (1959), Heir to Empire: United States Economic Diplomacy, 1916-1923, Fittsburgh: Press.

Redmond, John (1980), "An Indicator of the Effective Exchange Rate of the Found in the 1930's," Economic History Review, pp. 83-91.

Rogoff, K. (1983), "Yroductive and Counterproductive Monetary Policies," International Finance Discussion Paper 223 (Board of Governors of the Federal Reserve system), Deceniber.

Sauvy, Alfred (1984), Histoire Economique de la France entre les Deux Guerres, Paris: Econonica (second edition).

Sayers, Richard S. (1936), Bank of England Operations, 1890-1914, London, P.S. King.

Sayers, Richard 5. (1976), The Bank of England 1891-1944, Canbridge: Cambridge University Press.

Silverman, Dan F. (1982), Reconstructinq Europe After the Great war, Cambridge, Massachusetts: Harvard University Press. 
Svennilson, I. (1954), Growth and Stagnation in the European Economy, Geneva: United Nations.

Traynor, Dean E. (1949), International Monetary and Financial Conferences in the Interwar Period, Washington, D.C.: Catholic University of America Press.

Triffin, Fobert (1964), "The Myth and Realities of the So-Called Gold Standard," in The Evolution of the International Monetary System:

Historical Reaporaisal and Future Ferspectives, Princeton: Princeton University Press.

United Kingdom (1922), Correspondence between His Majesty's Government and the French Government Respecting the Genoa Conference, Cond. 1742, London: HMSO.

(1924), Papers Felating to International Economic Conference, Genoa, April-May 1922, Cod. 1667, London: HMso.

United Nations (1949), International Capital Movements During the Inter-War Period, New York: United Nations.

Viner, Jacob (1932), "International Aspects of the Gold Standard," in Quiney Wright (Ed.), Gold and Monetary Statilization, Chicago: University of Chicago Fress. 